V. Morkun, Dr. Sc. (Tech.), Prof., orcid.org/0000-0003-1506-9759, I. Kotov, Cand. Sc. (Tech.), Assoc. Prof., orcid.org/0000-0003-2445-6259
State Institution of Higher Education "Kryvyi Rih National University”, Kryvyi Rih, Ukraine, e-mail: morkunv@gmail. com; rioexito@gmail.com

\title{
INFORMATION TECHNOLOGIES FOR POWER SUPPLY DISPATCH CONTROL BASED ON LINGUISTIC CORPUS ONTOLOGIES
}

Purpose. Developing methods and algorithms of smart decision support systems (DSS) and their implementation as a component of automated dispatch control systems (ADCS) in power systems.

Methodology. The unitized method is applied to presenting professional ontologies. A model of signal-flow labeling is offered to control knowledge.

Findings. The research results in a unitized approach to incorporating professional ontologies to build smart decision support systems and automate complex-structured objects, which is noted for implementing unity of forms of knowledge representation. All knowledge forms are described by a single model of ontologies, which enables unitizing the mechanism of representing and processing knowledge of grid modes in power systems. The mathematical apparatus of ontology representation and application is improved and differs from existing ones by the fact that it is based on fundamental forms of knowledge representation independent of subject areas. The basic model of an elementary signal-flow graph of the knowledge base is elaborated. There are introduced formalisms of the labeling parameter and functions of labeling the elementary signal-flow graph of the knowledge base. A factual knowledge base is built considering subsets of the linguistic corpus of accident elimination and prevention in power systems. A specialized thesaurus of professional terms and slang of accident elimination and prevention in power systems is built.

Otiginality. For the first time, the research suggests a unitized approach to representing and controlling professional knowledge of dispatch emergency control based on the signal-flow graph. This enables creating efficient decision-support systems and implementing them into the current ADCS.

Practical value. The authors suggest forming new ontologies of knowledge bases for the area of dispatch control modes in the power system as sensitivity matrices based on factorial mode models. There are developed integral factors of thesaurus efficiency enabling assessment of efficiency of various forms of professional knowledge representation. The operating information and control complex (OICC) which is a structural scheme of integrating the DSS into the ADCS is developed to monitor power system modes on the basis of the empirical knowledge base for mode characteristics of the power system. After generalizing the results of testing the software complex while training dispatch personnel of the power system, it can be claimed that improved professional and psychological characteristics of operating personnel, reduced intensity of dispatch failures and conditional damage because of power undersupply indicate practical relevance of applying the DSS to controlling the power system under emergency modes.

Keywords: ontology, knowledge base, signal-flow graph, formal language, power system

Introduction. The structure of emergency control of the power system should be treated on two levels - that of automated control with emergency automation dominating and that of automated control with the operating dispatch personnel (ODP) as part of management with people making decisions [1].

Currently, there are accumulated results of emergency and accident analysis in power engineering reflected in many research works among which [2] is worth mentioning. Besides, let us provide generalized analysis data on failures at power plants, thermal and electric grids, power-generating and supplying companies and power systems of the National power company "Ukrenerho" [1]. According to the data provided, the number of breakdowns at Ukrainian power entities ranked as "the operating personnel's misactions" has increased by a quarter and makes $6.7 \%$ of the total number. Misactions of supervising personnel, repair, service and laboratory workers have increased by $6.6 \%$ making $17.8 \%$ of the total number. Misactions due to the influence of unauthorized people and entities have increased by $52.5 \%$ and make $6.8 \%$ of the total number. In total, process breakdowns caused by the personnel's wrong actions (the human error factor) make $31.3 \%$ among other factors.

In the mentioned cases, the ODP of power entities bear specific responsibility. In fact, the ODP functions as a series of decisions based on on-line data. Decisions are made either under the standard established mode of the power system or under the developing emergency mode. In the former case, the dispatch personnel do not feel any psychological pressure making verified decisions as they have enough time to assess a situation and work out a decision. In the latter case, under the

(C) Morkun V., Kotov I., 2019 emergency mode, when the issue of system stability is urgent, the ODP have to make responsible and not always evident decisions in the shortest time possible and bear significant responsibility for material damage and human lives.

Conducted analysis enables concluding that the total number of breakdowns and emergencies has not dropped while damages associated with them are aggravating. As a result, the problem of enhancing reliability of the ODP functioning as part of the ADCS is of immediate interest.

The issue of making managerial decision-making automated in emergency cases is to be considered through elaborating and implementing smart systems of managerial decision-support systems. The centerpiece of these systems is complexes of controlling expert knowledge [3] and their application is increasing both in engineering and economy [4].

Literature review. Profound critical and generalizing analysis of the research studies into knowledge control systems is observed in [5] that considers 54 journals. [6] deals with taxonomy of strategies of applying knowledge control systems to small and medium businesses. There are gradated areas, channels and scales of applying smart data as well as tools of their procession.

Extensive actual domestic and foreign materials classifying accidents at large-scale engineering entities including power complexes and nuclear power plants are found in [7].

It should be noted that synthesis and mathematical simulation of non-linear transient dynamic systems is also topical [8]. The hierarchical system of production management calls for automation and restructuring [9]. Consideration of dynamically changing conditions of a manufacturing process and requirements to managers' training is of particular importance [10].

Therefore, current development of industrial systems and economic conditions of their functioning applies new high requirements to their management. 
Basic requirements include: efficient choice of generating sources, integration of various power sources into the power system, automated elimination of consequences of emergency conditions in power systems, etc.

The mentioned problems are solved through step-by-step transition of power systems into smart power ones (SPS), a variety of SmartGrid systems which has become a worldwide trend at present [11]. The SPS is noted for its independent decision-making, self-diagnostics and self-recovery.

Basic functions of the SPS and smart emergency control systems (ECS) are performed through a set of digital devices and IT elements of the SPS. The main SPS unit is a digital substation [12]. Fig. 1 presents a diagram of information channels of a hardware-software complex (HSC) of a digital substation.

A digital substation is a highly automated substation in which almost all processes of information exchange among computer elements and that with external systems as well as computer performance control are performed digitally on the basis of protocols of the International Electrotechnical Commission - IEC 61850 (Systems and communication networks of substations).

Conducted analysis of many research and scientific-practical works enables concluding that creation of smart power systems and facilities is promising, yet at present, there are some objective difficulties of implementing these projects.

Dispatch-advisers, smart software and hardware complexes, can be regarded as the most balanced and efficient solution of the problem of automatizing ECSs within the ADCS of power systems. Dispatch advisers are software-hardware complexes of decision support systems (DSS) based on artificial intelligence technologies. There is great domestic and international experience of DSS creation in the area of power system management.

Such scholars and engineers as Antonova N. N., Bashlykov A.A., Berdnikov R. N., Vagin V.N., Venikov V.A., Voronenko D. I., Voropay N. I., Galanov V.I., Gelovani V.A., Yeremeev A.P., Eremeev L.P., Koshcheev L.A., Kupershmidt Yu. Ya., Larin O.M., Lebedev L.S., Lyubarskiy Yu. Ya., Morzhin Yu. I., Panasetskiy D. A., Pospelov D. A., Samoylov V.D., Soloviev S.Yu., Stogniy B.S., Terelyanskiy P. V., Horoshevskiy V.F., Chachko A. G. and others contributed much to the theory of intellectualization of emergency and dispatch control of power systems, DSSs of power engineering.

Unsolved aspects of the problem. The knowledge system of a narrow professional area used in [1] does not allow generalization of the suggested experience. [3] applies upper-level meta-data to building expert systems, but there is no single method for elaborating meta-rules for various professional areas.

[13] deals with the problem of knowledge representation and suggests a table-oriented system of storage noted for some

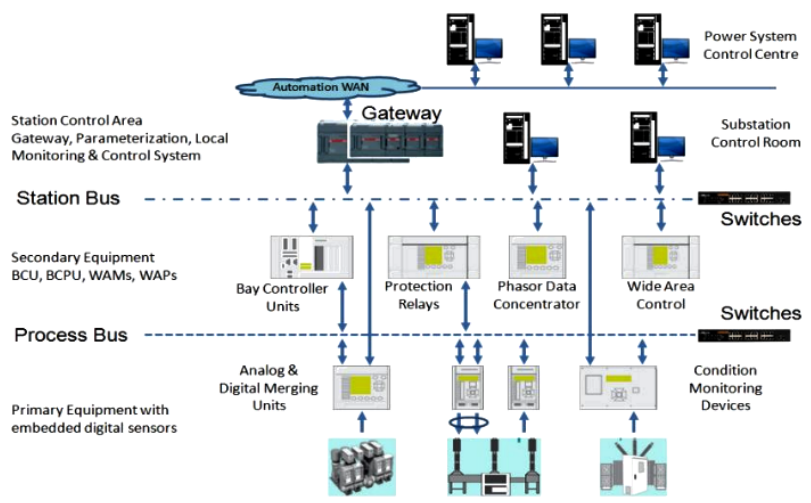

Fig. 1. Generalized structure of the information complex of the digital substation [12] known constraints. Besides, issues of controlling knowledge systems are neglected. [14] contains general methods for building expert systems without any particular approaches to implementing a meta-knowledge model. [15] considers methods for presenting data on processes under uncertainty conditions, yet they are not expressed as meta-rules.

Thus, there is a methodological problem of building knowledge systems which are invariant in relation to specific subject areas, knowledgebase structures, forms of knowledge representation, applied formal models and imposed constraints.

Summarizing the conducted analysis, we should note that there is a problem of a lack of a unitized model of theoretical representation and practical creation of knowledge models in smart systems. This does not enable mass production of cheap software systems of decision support.

Purpose. Conducted analysis allows formulating a research aim that implies development of mathematical models and methods for building unitized ontologies to create systems of managerial decision support of power dispatchers. Here, basic DSS functions should be considered. They all can be grouped into two primary directions:

- identifying an emergency;

- working out control actions.

The problems of emergency identification should be solved by methods of recognition (classification). In this case, guided by sampling (with known disturbance, the character of the transient process and assessment of emergency severity), one builds a function of measured parameters of the mode and disturbance that distributes modes by severity classes. Methods of the theory of image recognition enable subclasses of emergency modes of various severity rates.

To perform this, there are some planned experiments on dispatch actions on the power system grid. The knowledge base is filled with images of emergency modes of the power system and formalisms of dispatchers' decisions together with assessments of control actions in the form of sensitivity matrices.

The following tasks were set to achieve the research purpose:

- forming empirical sensitivity matrices of the power system of control actions on the basis of response functions;

- building professional ontologies based on empirical knowledge bases of mode characteristics of controlled areas of the power system;

- developing a base model of the knowledge-base signal graph;

- building a specific thesaurus of professional terms and slang;

- working out criteria for assessing efficiency of the thesaurus of factual collocations of the professional ontology of the linguistic corpus of accident elimination in the power system;

- substantiating practical applicability, value and significance of the developed models and criteria for efficiency of the thesauruses.

Methods. The problem of defining subsets of control units of the power system includes finding the transformation $Y=$ $=F(X)$ ( $X$ is an initial $n$-dimensional space of factors, $Y$ is a new $m$-dimensional space, $n>m$ ). The $Y$ space dimensionality should be minimal, yet sufficient for recognizing this classtaxon. Then, we solve a problem of selecting optimal control actions on the basis of the methods of the experiment planning theory.

Parameters characterizing a standard mode and disturbance as well as a grid structure are chosen as independent factors. A series of calculation experiments are conducted to determine optimal dosages of control actions to achieve a satisfactory mode. While building the experimental part of the knowledge base, the research considers dispatch control over power flow at the interchange of South-Ukraine Nuclear Power Plant-Vinnytsia (SUNPP-Vinnytsia) by affecting capacities of some large generating units. 
At developing professional ontologies, dispatch instructions are used as an initial expert linguistic corpus.

Efficiency of the obtained ontology model is verified by building its thesaurus. A limited linguistic corpus concerning emergency and accident elimination and prevention in the electric part of a power station and electric grids is chosen for sampling lexical blocks of factual collocations. Facts are formed on the basis of fixed linguistic forms of the profession$\mathrm{al}$ area. The obtained collocations result in a general thesaurus of the lexical corpus that provides the basis for the thesaurus of specific terms and slang.

Results. The knowledge base is built by combining dispatcher instructions as for controlling active power flow in a particular intersection and new knowledge obtained from experimental data on mode investigations.

To assess parameters of the studied cluster of the electric grid of the power system, we use a model of equations of the set mode as a power balance in the nodes

$$
\dot{\omega}_{s k}(\dot{U})=\dot{S}_{k}^{*}-\dot{Y}_{k k} \dot{U}_{k} \dot{U}_{k}^{*}-\sum_{j=1, j \neq k}^{N} \dot{Y}_{k j} \dot{U}_{j} \dot{U}_{k}^{*},
$$

where $\omega_{s_{k}}(\dot{U})$ is a function of power imbalance in the node $k$; $S_{k}^{*}$ is a conjugate complex of power of the $k^{\text {th }}$ node; $\dot{Y}_{k k}$ is conductivity of the kth node; $\dot{U}_{k}$ is a complex of voltage of the kth node; $\dot{U}_{k}^{*}$ is a conjugate complex of voltage of the kth node; $\dot{Y}_{k j}$ is mutual conductivity of the kth and the jth nodes; $N$ is the number of nodes in the studied cluster.

For the sake of practical applicability of model (1), variables are presented as real numbers in polar coordinates

$$
\begin{aligned}
& w_{P k}(U)=P_{k}-g_{k k} U_{k}^{2}-U_{k} \sum_{\substack{j=1 \\
j \neq k}}^{N} U_{j}\left(g_{k j} \cos \delta_{k j}-b_{k j} \sin \delta_{k j}\right) ; \\
& w_{Q k}(U)=Q_{k}-b_{k k} U_{k}^{2}-U_{k} \sum_{\substack{j=1 \\
j \neq k}}^{N} U_{j}\left(b_{k j} \cos \delta_{k j}+g_{k j} \sin \delta_{k j}\right),
\end{aligned}
$$

where $\delta_{k j}=\delta_{k}-\delta_{j}, \delta_{k}, \delta_{j}$ are phase angles of vectors of voltage modules of the $k^{\text {th }}$ and jth nodes.

Conducted calculation and analytical experiments result in sets of response functions for control actions in the set nodes of the grid. The obtained regression models are relevant for describing the impact of capacities of selected controlling substations on the value of active power flow in the intersection of the SUNPP-Vinnytsia and can be applicable to forming control dispatch actions.

After fixing separate regression parameters on zero levels, illustrations of generating stations impacting power flow in the intersections are obtained and presented in Fig. 2.

Experimentally revealed dispatch actions and emergency control instructions provide the basis for building a knowledge base. A formal model of professional ontology is suggested as the basis for the unitized knowledge base. In the most general form, the ontology can be presented by the following formal specification

$$
\mathrm{O}=\langle X, R, F\rangle,
$$

where $X$ is a finite set of concepts (notions, terms) of the subject area presented by the ontology $O ; R$ is a finite set of relations among concepts (notions, terms) of the set subject area; $F$ is a finite set of interpretation (axiomatization) functions set on the concepts and/or relations of the ontology $O$.

In the ontology, sets of relations among concepts should be realized through the signal-flow graph model (Fig. 3) [16].

The following formulae are characteristic of labeling of corresponding nodes $p_{i}, p_{j}$ and the edge $b_{i j}$

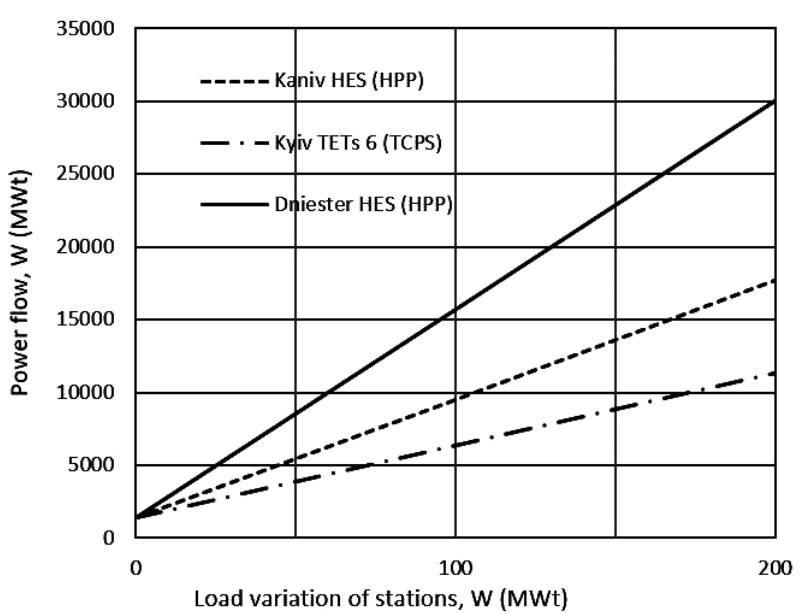

Fig. 2. Experiment data on the impact of capacities of generating stations on active power flow in the intersection of the SUNPP-Vinnytsia

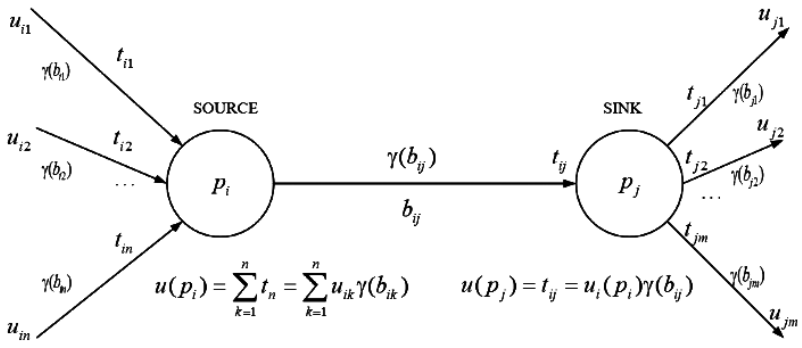

Fig. 3. Basic model of transmitting a signal in the elementary signal-flow graph

$$
\begin{gathered}
\mu_{i}^{p}=\left\langle c_{s}\left(p_{i}\right), u\left(p_{i}\right), s_{u}\left(p_{i}\right), a\left(p_{i}\right)\right\rangle ; \\
\mu_{j}^{p}=\left\langle c_{s}\left(p_{j}\right), u\left(p_{j}\right), s_{u}\left(p_{j}\right), a\left(p_{j}\right)\right\rangle ; \\
\mu_{i}^{b}=b_{i} \rightarrow \gamma\left(b_{i}\right) .
\end{gathered}
$$

An atomic concept $\left(\mathrm{c}_{s}\right)$ is a proposition set for the signalflow graph node and regarded as a whole while interpreting and calculating the knowledge base.

A signal $(t)$ is a digital concept characterizing a possible cause-effect relation among nodes of the signal-flow graph. In this particular case, a signal can be interpreted as implication provided with a digital characteristic of signal movement or propagation. In other words, if there is a signal between the graph edge, the cause-effect relation between the nodes incident by this edge is active.

The node potential (node signal), $u \in \mathbb{R}$, is a number (generally real), assigned to a node and associated with it in the current interpretation of the system functioning. The numbers associated with nodes can be interpreted as weights, potentials and tokens of nodes. There are no critical constraints imposed on node potentials

Node activity, $a=(0 \mid 1)$, is a binary sign characterizing the role of the node in grid interpretation. If the node is not active $(a=0)$, it is not interpreted by the logic input block (machine), does not participate in the logic conclusion and its content is ignored.

Sensitivity threshold of the node as to the input signal, in its general form $s_{u}=f\left(t_{m}\right)$, is a degree of node capacity to pass an input signal to subsequent incident edges where $t m$ is a threshold signal level. The form of the function $f\left(t_{m}\right)$ is determined by simulation aim and tasks. When exceeding sensitivity threshold $s_{u}$, the node $p_{i}$ is activated, and a signal of the set value $t\left(p_{i}\right)$ is fixed. Signals below $s_{u}$, are not perceived by the node 


$$
\begin{gathered}
a\left(p_{i}\right)=\left\{\begin{array}{l}
0 \mid t\left(p_{i}\right) \leq s_{u}\left(p_{i}\right) \\
1 \mid t\left(p_{i}\right) \leq s_{u}\left(p_{i}\right)
\end{array}\right. \\
u\left(p_{i}\right)=\left\{\begin{array}{l}
0 \mid t\left(p_{i}\right) \leq s_{u}\left(p_{i}\right) \\
u\left(p_{i}\right) \mid t\left(p_{i}\right) \leq s_{u}\left(p_{i}\right)
\end{array}\right.
\end{gathered}
$$

Let us introduce a labeling function of the $i^{\text {th }}$ node of the signal-flow graph of the knowledge base. We determine the labeling parameter through the tuple

$$
m_{\mu}=\left\langle c_{s}, u, s_{u}, a\right\rangle .
$$
by

Then, the labeling for the arbitrary $i^{\text {th }}$ node is determined

$$
\begin{gathered}
\mu_{i}^{p}: p_{i} \rightarrow m_{\mu}\left(p_{i}\right)=\left\langle c_{s}\left(p_{i}\right), u\left(p_{i}\right), s_{u}\left(p_{i}\right), a\left(p_{i}\right)\right\rangle ; \\
\mu_{i}^{p} \in M^{p} ; \quad p_{i} \in P\left(G_{s}\right) ; \\
M^{p}: P\left(G_{s}\right) \rightarrow m_{\mu}(P) ; \quad u\left(p_{i}\right), s_{u}\left(p_{i}\right) \in \mathbb{R},
\end{gathered}
$$

where $\mu_{i}^{p}$ is a labeling function of the $i^{\text {th }}$ node $p_{i}$ by the parameter $c\left(p_{i}\right) ; M^{p}$ is general labeling of cluster nodes (or the whole grid) to which the meta-knowledge model is applied; $P\left(G_{s}\right)$ is a set of cluster nodes (or the whole grid) to which the metaknowledge model is applied; $\mathbb{R}$ is a set of real numbers.

The edge $b_{j k}$ between nodes $j$ and $k$ of the knowledge representation structure of any level will be regarded as a directed relation (connection, edge) between these nodes in the signalflow graph of the knowledge base. Each edge has its input and output potentials (signals). If the edge is directed from the node $j$ towards the node $k$, the node $j$ of the potential $u_{j}$ will be the source one, while the node $k$ of the potential $u_{k}$ will be the drain one. By using symbols established earlier, the graph edge of the knowledge base will look as

$$
I: b_{j k} \rightarrow\left(p_{j}, p_{k}\right) ; \quad b_{j k} \in A\left(G_{s}\right) ; \quad p_{j}, p_{k} \in A\left(G_{s}\right),
$$

where $b_{j k}$ is a graph edge of the grid; $I$ is an incidence function; $A\left(G_{s}\right)$ is a set of all edges of the graph $G_{s}$ of the grid on the knowledge base level; $p_{j}, p_{k}$ are nodes, incident edges of $b_{j k}$.

Conductivity (transmission) of an edge, $\gamma(b)$, is a number (in a general case, real) associated with the edge. The purpose of numbers is labeled. The numbers associated with edges can be treated as weights, conductivities, lengths, costs of edges, etc. There are no constraints imposed on these numbers. Let us assume that the numbers indicating edges are conductivities of these edges.

We introduce a labeling function of the $i^{\text {th }}$ edge in the following way

$$
\begin{gathered}
\mu_{i}^{b}: b_{i} \rightarrow \gamma\left(b_{i}\right) ; \quad \mu_{i}^{b} \in M^{b} ; \\
M^{B}: A\left(G_{s}\right) \rightarrow \mathbb{R} ; \quad b_{i} \in A\left(G_{s}\right) ; \quad \gamma\left(b_{i}\right) \in \mathbb{R},
\end{gathered}
$$

where $\mu_{i}^{b}$ is a labeling function of the $i^{\text {th }}$ edge $b_{i}$ by the number $t_{i} ; M^{B}$ is general labeling of cluster edges (or the whole grid) to which the meta-knowledge model is applied; $A\left(G_{s}\right)$ is a set of directed edges of the cluster graph (or the whole grid) to which the meta-knowledge model is applied; $\mathbb{R}$ is a set of real numbers.

Now, the suggested generalized model of the graph on the knowledge base structure level can be described by the following tuple

$$
G_{s}=\left(P\left(G_{s}\right), A\left(G_{s}\right), M_{\Sigma}\right) ; \quad M_{\Sigma}=\left\langle M^{p}, M^{B}\right\rangle .
$$

The suggested models of labeling graph nodes and edges and signal propagation to simulate the logic conclusion process are noted for the possibility to dynamically form clusters of smart grids. These grids can be treated as sets of facts in particular.

A fact can be presented by the following formal tuple

$$
f_{i}^{c j}=\left\langle S_{s i}^{c j}, S_{r i}^{c j}, S_{a i}^{c j}\right\rangle,
$$

or in theoretical and multiple interpretation as

$$
f_{i}^{c j}=\left\{S_{s i}^{c j}, S_{r i}^{c j}, S_{a i}^{c j}\right\} .
$$

The subset of facts $F^{c j}$ relating to the context $c_{j}$ of the general set of facts $F$ will be presented as follows

$$
\begin{aligned}
& f_{i}^{c j} \in F^{c j} ; \\
& F^{c j} \subseteq F .
\end{aligned}
$$

On the basis of the set theoretical and multiple model of the elementary fact, we formalize its graph model. The elementary fact $f i$ in its general form is presented by the graph

$$
G_{i}^{f}=\left\{V(G)_{i}^{f}, A(G)_{i}^{f}\right\}
$$

where $V(G)_{i}^{f}=f_{i}^{c j}$ is a set of atomic propositions forming the fact

$$
\begin{gathered}
f_{i}^{c j}=\left\{S_{s i}^{c j}, S_{r i}^{c j}, S_{a i}^{c j}\right\},\left|V(G)_{i}^{f}\right|=3 ; \\
A(G)_{i}^{f},\left|A(G)_{i}^{f}\right|=2,
\end{gathered}
$$

where $A(G)_{i}^{f}$ is a set of edges (connections).

Besides, for the fact, we introduce private interpretation of node movement which depends on the problem conditions and, in a general case, can be arbitrary

$$
I^{f}=\left(P_{s}^{f}, P_{e}^{f}\right)
$$

where $P_{s}^{f}$ is an incidentor of initial propositions of fact edges $P_{s}^{f}\left(S_{s i}^{c j}, S_{r i}^{c j}\right)=S_{s i}^{c j}$ and $P_{s}^{f}\left(S_{r i}^{c j}, S_{a i}^{c j}\right)=S_{r i}^{c j} ; \quad P_{e}^{f}$ is an incidentor of final propositions of fact edges $P_{e}^{f}\left(S_{s i}^{c j}, S_{r i}^{c j}\right)=S_{r i}^{c j}$ and $P_{e}^{f}\left(S_{r i}^{c j}, S_{a i}^{c j}\right)=S_{a i}^{c j}$.

Now, we can provide a general formal model of the elementary fact graph

$$
G_{i}^{f}=\left\{V(G)_{i}^{f}, A(G)_{i}^{f}, I^{f}\right\} ; \quad G_{i}^{f}=\left\{V(G)_{i}^{f}, A(G)_{i}^{f}, P_{s}^{f}, P_{e}^{f}\right\} .
$$

To form a knowledge base based on facts, we develop a formal language. The subset of elementary facts of the knowledge base of the smart system is connected with $c_{i}^{\text {th }}$ context

$$
F^{c j}=\left\{f_{k}^{c j} \mid k=1, n_{f}\right\}, \quad F^{c i} \subset F,
$$

where $n_{f}$ is the number of elementary facts connected with $c_{i}^{\text {th }}$ context.

Considering classification of facts for the subset $F^{c i}$ by indicators (contexts) $g_{m}^{f c i}$ we can write down

$$
F^{c i}=\left\{\left\{F_{1 g_{m}^{c i}}^{c i}\right\},\left\{F_{2 g_{m}^{c i}}^{c i}\right\}, \ldots,\left\{F_{m g_{m}^{c i}}^{c i}\right\}, \ldots,\left\{F_{n_{g} g_{m}^{c i}}^{c i}\right\}\right\},
$$

where $\left\{F_{m g_{m}^{c i}}^{c i}\right\}$ is a class of facts corresponding to the classifying indicator $g_{m}^{f c i}$.

If we assume that all elementary facts have no duplicates, properties of elementary facts of the knowledge base should be the following

$$
\begin{gathered}
F^{c i}=F_{1 g_{m}^{c i}}^{c i} \cup F_{2 g_{m}^{c i}}^{c i} \ldots \bigcup F_{m g_{m}^{c i}}^{c i} \ldots \cup F_{n_{g} g_{m}^{c i}}^{c i}=\bigcup_{m=1}^{n_{g}} F_{m g_{m}^{c i}}^{c i} \\
F_{1 g_{m}^{c i}}^{c i} \cap F_{2 g_{m}^{c i}}^{c i} \ldots \cap F_{m g_{m}^{c i}}^{c i} \ldots \cap F_{n_{g} g_{m}^{c i}}^{c i}=\bigcap_{m=1}^{n_{g}} F_{m_{m}^{c i}}^{c i}=\varnothing ;
\end{gathered}
$$




$$
\begin{gathered}
\forall F_{m g_{m}^{c i}}^{c i}\left(F_{m g_{m}^{c i}}^{c i} \subseteq F^{c i}\right) ; \\
\forall F_{p g_{m}^{c i}}^{c i} \forall F_{q g_{m}^{c i}}^{c i}\left(F_{p g_{m}^{c i}}^{c i} \neq F_{q g_{m}^{c i}}^{c i}\right) .
\end{gathered}
$$

We should consider that the formal language of facts corresponds to a particular subject area, i. e. belongs to some class of facts $G^{c i}$ in the current context

$$
\forall F_{k}^{c i}, \quad k=1, n_{f}\left(\begin{array}{c}
m=1 \\
\underset{n_{g}}{\vee}
\end{array} f_{k}^{c i} \in F_{m g_{m}^{c i}}^{c i}\right) .
$$

The language of elementary facts for the subject area $c_{i} \in C$ and some $m^{\text {th }}$ class $g_{m}^{c i}$ is determined as follows

$$
L(G)_{g_{m}^{c i}}^{f c i}=\left\langle\Sigma^{f}, N^{f}, P^{f}, S^{f}\right\rangle
$$

where $G$ is formal grammar based on facts; $\sum f$ is a basic finite terminal alphabet; $N^{f}$ is an auxiliary finite non-terminal alphabet; $P^{f}$ is rules of substitution (production) of formal grammar based on facts: $\exists a \exists b(a, b) \in P: a \rightarrow b ; S^{f}$ is a starting non-terminal symbol of grammar $G$ based on facts; $N^{f} \cap \Sigma^{f}=$ $=\varnothing$ and

$$
P \subset\left(N^{f} \cup \Sigma^{f}\right)^{+} \times\left(N^{f} \cup \Sigma^{f}\right)^{*} .
$$

We determine formal grammar rules $P$ based on facts for the language $L(G)_{g_{m}^{c i}}^{f c i}$

$$
\begin{gathered}
f \rightarrow\langle\text { lexeme }\rangle\langle\text { lexeme }\rangle\langle\text { lexeme }\rangle\langle\text { lexeme }\rangle \rightarrow \\
\rightarrow\langle\text { lexeme }\rangle \mid\langle\text { proposition }\rangle .
\end{gathered}
$$

Let us generalize the language of facts to all the classes of contexts of knowledge bases based on facts.

$$
L(G)^{f}=\left\langle\Sigma^{f}, N^{f}, P^{f}, S^{f}\right\rangle,
$$

where $\Sigma^{f}=F=\left\{f_{k} \mid k=1, n_{f}\right\}$ are all the facts of the knowledge base fact level; $F=\left\{\left\{F_{1 g_{m}^{c i}}^{c i}\right\},\left\{F_{2 g_{m}^{c i}}^{c i}\right\}, \ldots,\left\{F_{m g_{m}^{c i}}^{c i}\right\}, \ldots,\left\{F_{n_{g} g_{m}^{c i}}^{c i}\right\}\right\} ; N^{f}=$ $=\{$ fact , class_of facts, layer_of facts $\} ; S^{f}=\langle$ layer_of facts $\rangle$.

While generalizing, we provide a structural and linguistic model of ontology for the knowledge base level of elementary facts $-K B_{F}$

$$
O_{K B f}=\left\langle X^{f}, R^{f}, F^{f}\right\rangle .
$$

There are suggested the following criteria for assessing efficiency of fact thesauruses.

The first indicator assesses absolute efficiency expressed quantitatively by symbols (or bites) as redundancy eliminated by using a general or a specific thesaurus

$$
\begin{gathered}
E_{F T}^{a b s}={ }_{\Delta} V_{F-F T}=V_{F}^{+}-V_{F T}^{+} ; \\
E_{F T A}^{a b s}={ }_{\Delta} V_{F-F T A}=V_{F}^{+}-V_{F T A}^{+} .
\end{gathered}
$$

Absolute values of thesaurus efficiency indicate stable growth of redundancy of the initial linguistic corpus in comparison with other dictionaries. Yet, thesauruses also become larger. The ratio of absolute efficiency to the amount of the fact base incrementally is of particular interest. To check this, the research suggests another indicator of thesaurus efficiency - relative efficiency

$$
\begin{aligned}
E_{F T}^{r e l} & =\frac{E_{F T}^{a b s}}{V_{F}^{+}} \cdot 100 \%=\frac{V_{F}^{+}-V_{F T}^{+}}{V_{F}^{+}} \cdot 100 \% ; \\
E_{F T A}^{r e l} & =\frac{E_{F T A}^{a b s}}{V_{F}^{+}} \cdot 100 \%=\frac{V_{F}^{+}-V_{F T A}^{+}}{V_{F}^{+}} \cdot 100 \% .
\end{aligned}
$$

Indicators of relative efficiency of professional thesauruses are informative and relevant enough to reflect a semantic and quantitative character of the fact base of the linguistic corpus of accident elimination in the power system. Yet, these indicators change while the knowledge base accumulates and when several specific areas are combined. Therefore, there arises a necessity to have a stable integral indicator of thesaurus efficiency. So, the research suggests the third indicator - an integral factor of thesaurus efficiency. It is calculated by means of linear approximation of indices of absolute thesaurus efficiency.

Expressions for calculating integral factors of efficiency of corresponding general and professional thesauruses of abbreviations and slang are given in the form of the formulae

$$
\begin{gathered}
K_{E T}=\left(1-\frac{\alpha_{T}}{\alpha_{B}}\right) \cdot 100 \%=\left(1-\frac{\operatorname{arctg}\left(a_{T}\right)}{\operatorname{arctg}\left(a_{B}\right)}\right) \cdot 100 \% ; \\
K_{E T A}=\left(1-\frac{\alpha_{T}}{\alpha_{B}}\right) \cdot 100 \%=\left(1-\frac{\operatorname{arctg}\left(a_{T A}\right)}{\operatorname{arctg}\left(a_{B}\right)}\right) \cdot 100 \%,
\end{gathered}
$$

where $K_{E T}$ is an efficiency factor of the general thesaurus; $K_{E T A}$ is an efficiency factor of the abbreviation and slang thesaurus; $\alpha_{T}$ is a slope angle of the approximated straight line for the general thesaurus; $\alpha_{T A}$ is inclination of the approximated straight line for the abbreviation and slang thesaurus; $\alpha_{B}$ is inclination of the approximated straight line for the fact base; $a_{T}$ is a factor under $V_{K B}$ in the straight line equation for the general thesaurus; $a_{T A}$ is a factor under $V_{K B}$ in the straight line equation for the abbreviations and slang thesaurus; $a_{B}$ is a factor under $V_{K B}$ in the straight line equation for the fact base.

Graphical results of approximation and explanations of calculations are given in Fig. 4.

The physical meaning of the integral factor of thesaurus efficiency is a ratio of inclination of the approximated straight line of the thesaurus growth speed to the inclination of the approximated straight line of the growth speed of the initial base.

Substitution of calculated values provides the following results,

$$
\begin{gathered}
K_{E T}=\left(1-\frac{\operatorname{arctg}(0.2751)}{\operatorname{arctg}(1)}\right) \cdot 100 \%=65.82 ; \\
K_{E T A}=\left(1-\frac{\operatorname{arctg}(0.1439)}{\operatorname{arctg}(1)}\right) \cdot 100 \%=81.81 .
\end{gathered}
$$

Thus, calculations indicate that efficiency of the general thesaurus makes $65.82 \%$, while that of abbreviations and slang is $81.88 \%$. As a result, efficiency of application of knowledge bases increases when the DSS professional area is more

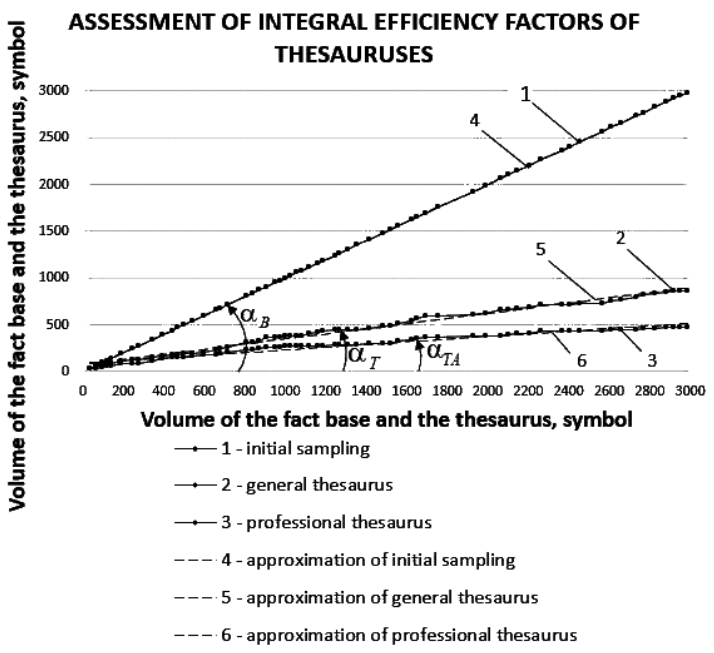

Fig. 4. Calculation of integral factors of thesaurus efficiency 
specific. The professional area of emergency control over power system modes is highly specific and building its thesaurus is very reasonable.

Conclusions.

1. The basic model of elementary signal-flow graph of the knowledge base is developed. The rule of signal propagation is substantiated which is based on potentials of nodes set by the labeling function and can be dynamically changed in the course of signal movement.

2. The model of labeling a signal-flow graph of the knowledge base is substantiated and developed. The model includes labeling of graph nodes and edges by providing them with parameters of labeling - concept meaning, node potential, sensitivity threshold of the node, indicators of node activity, edge conductivity (transmission).

3. The specific thesaurus of professional terms and slang of accident elimination and prevention in the power system is built.

4. The initial lexical sampling and professional thesauruses are statistically processed.

5. Absolute, relative and integral indicators of efficiency of the thesaurus of factual collocations of the linguistic corpus of accident elimination in the power system are elaborated.

6. Practical applicability, value and significance of the developed models and criteria for assessing efficiency of thesauruses are confirmed.

It is evident that the efficiency of application of ontology models to general lexis will be much lower because of the necessity of using a larger thesaurus. That is why, ontology models should be applied to specific professional areas noted for a wider scope of professional terminology (professional slang and abbreviations). By using the research results, ontology models for various knowledge representation forms are planned to be built.

\section{References.}

1. Antamoshin, A. N., Bliznova, O.V., Bobov, A.V., Bolshakov, A. A., Lobanov, V.V., \& Kuznetsova, I. N. (2016). Smart systems of controlling organization and technical schemes. Moscow: Goryachaya liniya-Telekom. ISBN: 978-5-9912-0576-4. 2. Muhamedzhanova, Ye. R., \& Akatyev, V.A. (2017). Analysis of large accidents at radiation entities and their impact on global atomic power engineering. Globalnaya yadernaya bezopasnost - Global security, 3(24), 110-114. ISSN: 2305-414X.

3. Barkalov, S.A., Dushkin, A. V., Kolodyazhnyi, S.A., \& Sumin, V. I. (2017). Introduction to system design of smart knowledge bases: monograph. Moscow: Goryachaya liniya - Telekom. ISBN: 978-5-9912-0589-4.

4. Cepeda-Carrion, I., Martelo-Landroguez, S., Leal-Rodríguez, A. L., \& Leal-Millán, A. (2017). Critical processes of knowledge management: An approach toward the creation of customer value, European Research on Management and Business Economics, 23(1), 1-7. https://doi.org/10.1016/j.iedeen.2016.03.001.

5. Iskandar, K., Jambak, M.I., Kosalaa, R., \& Prabowo, H. (2017). Current Issue on Knowledge Management Systemfor future research: a Systematic Literature Review. $2^{\text {nd }}$ International Conference on Computer Science and Computational Intelligence 2017. ICCSCI 2017, 13-14 October 2017, Bali, Indonesia, Procedia Computer Science, 116(2017), pp. (68-80). https://doi.org/10.1016/j.procs.2017.10.011.

6. Cerchione, R., \& Esposito, E. (2017). Using knowledge management systems: A taxonomy of SME strategies. International Journal of Information Management, 37, 1551-1562. https://doi.org/10.1016/j.ijinfomgt.2016.10.007.

7. Arutyunyan, R. V., Bolshov, L. A., Borovoy, A.A., \& Velihov, E. P. (2018). System analysis of causes and consequences of the accident at NPP Fukusima-1. Moscow: In-t problem bezopasnogo razvitiya atomnoy energetiki RAN. ISBN 978-59907220-5-7.

8. Morkun, V., Morkun, N., \& Tron, V. (2015). Model synthesis of nonlinear nonstationary dynamical systems in concen- trating production using Volterra kernel transformation. Metallurgical and Mining Industry, 7(10), 6-9.

9. Golik, V., Komaschenko, V., Morkun, V., \& Khasheva, Z. (2015). The effectiveness of combining the stages of ore fields development. Metallurgical and Mining Industry, 7(5), 401405 .

10. Golik, V., Komashchenko, V., \& Morkun, V. (2015). Geomechanical terms of use of the mill tailings for preparation. Metallurgical and Mining Industry, 7(4), 321-324.

11. Sato, T., Kammen, D.M., Duan, B., Macuha, M., Zhou, Z., Wu, J., Tariq, M., \& Asfaw, A.S. (2015). Smart Grid Standards: Specifications, Requirements, and Technologies. John Wiley \& Sons Singapore Pte. ISBN: 978-1-118-65369-2. 12. Kasarpatil, K., Karadkar, T., \& Dudwadkar, A. (2015). Digital Substation and Case Study of Tata Power // International Journal of Emerging Technology and Advanced Engineering, 5(2), 134-141.

13. Miah, S.J., \& Genemo, H. (2016). A Design Science Research Methodology for Expert Systems Development. Australasian Journal of Information Systems, 20(0), 1-29. https:// doi.org/10.3127/ajis.v20i0.1329.

14. Duer, S., Wrzesień, P., \& Duer, R. (2017). Creating of structure of facts for the knowledge base of an expert system for wind power plant's equipment diagnosis. Web of Conferences, 1. https://doi.org/10.1051/e3sconf/20171901038.

15. Xamena, E., Brignole, N. B., \& Maguitman, A. G. (2017). A Structural Analysis of topic ontologies. Information Sciences, 421, 15-29. https://doi.org/10.1016/j.ins.2017.08.081.

16. Moschytz, G.S. (2019). An Introduction to Signal-Flow Graph Theory. In Analog Circuit Theory and Filter Design in the Digital World (pp. 85-100). Springer, Cham. https://doi. org/10.1007/978-3-030-00096-75.

\section{Інформаційні технології диспетчерського управління енергозабезпеченням на базі онтологій лінгвістичного корпусу}

\section{B. С. Моркун, I. А. Котов}

Державний вищий навчальний заклад „Криворізький національний університет“, м. Кривий Ріг, Україна, e-mail: morkunv@gmail.com; rioexito@gmail.com

Мета. Розробка методів і алгоритмів інтелектуальних систем підтримки прийняття рішень (СППР) та їх упровадження як складової частини автоматизованих систем диспетчерського керування (АСДК) енергосистем.

Методика. Використано уніфікований підхід до подання професійних онтологій. Для управління знаннями запропонована модель маркування сигнального графа.

Результати. У роботі сформовано єдиний підхід до інкорпорації професійних знань для побудови інтелектуальних систем підтримки прийняття рішень і автоматизації управління складно-структурованими об'єктами, які відрізняється тим, що одночасно реалізує єдність форм подання знань. Усі форми знань описуються єдиною моделлю онтологій, шо він дозволяє уніфікувати механізм подання та обробки знань про режими електричної мережі енергосистеми. Удосконалено математичний апарат подання й використання онтологій, що відрізняється від існуючих тим, що базується на фундаментальних формах подання знань, які не залежать від предметних областей. Розроблена базова модель елементарного сигнального графа бази знань (Б3). Уведені формалізми параметра маркування та функції маркування елементарного сигнального графа БЗ. Побудована фактуальная Б3 на основі підмножини лінгвістичного корпусу ліквідації й запобігання аварій в енергосистемі. Побудовано спеціалізований тезаурус професійних термінів і сленгу області ліквідації й запобігання аварій в енергосистемі. 
Наукова новизна. Уперше запропоновано уніфікований підхід до подання та управління професійними знаннями диспетчерського протиаварійного керування на базі моделі сигнального графа. Це дає можливість будувати ефективні системи підтримки прийняття рішень і впроваджувати їх у середовище діючої АСДК.

Практична значимість. У роботі запропоновано формування нових онтологій баз знань області диспетчерського управління режимами енергосистем у вигляді матриць чутливості на основі факторних режимних моделей. Розроблені інтегральні коефіцієнти ефективності тезаурусів, що дозволяють практично оцінити ефективність різних форм репрезентації професійних знань. Запропонована структурна схема інтеграції СППР у комплекс АСДК - оперативний інформаційно-керуючий комплекс (ОІКК) для моніторингу режиму електроенергетичної системи (EEC) на основі емпіричної бази знань про режимні характеристики енергосистеми. Узагальнення результатів випробувань програмного комплексу при тренуваннях диспетчерського персоналу енергосистеми підтвердило практичну значимість застосування СППР у практиці диспетчерського керування ЕЕС в аварійних ситуаціях: підвищилися професійно-психологічні характеристики оперативного персоналу, скоротилися інтенсивність відмов диспетчерських змін і умовний збиток від недовідпуску електроенергії.

Ключові слова: онтологія, база знань, сигнальний граф, формальна мова, енергосистема

\section{Информационные технологии диспетчерского управления энергообеспечением на базе онтологий лингвистического корпуса}

\section{В. С. Моркун, И. А. Котов}

Государственное высшее учебное заведение „Криворожский национальный университет“, г. Кривой Рог, Украина, e-mail: morkunv@gmail.com; rioexito@gmail.com

Цель. Разработка методов и алгоритмов интеллектуальных систем поддержки принятия решений (СППР) и их внедрения как составной части автоматизированных систем диспетчерского управления (АСДУ) энергосистем.

Методика. Использован унифицированный подход к представлению профессиональных онтологий. Для управления знаниями предложена модель маркировки сигнального графа.

Результаты. В работе сформирован единый подход к инкорпорации профессиональных знаний для построения интеллектуальных систем поддержки принятия ре- шений и автоматизации управления сложно-структурированными объектами, отличающийся тем, что он одновременно реализует единство форм представления знаний. Все формы знаний описываются единой моделью онтологий, что позволяет унифицировать механизм представления и обработки знаний о режимах электрической сети энергосистемы. Усовершенствован математический аппарат представления и использования онтологий, отличающийся от существующих тем, что основан на фундаментальных формах представления знаний, не зависящих от предметных областей. Разработана базовая модель элементарного сигнального графа базы знаний (Б3). Введены формализмы параметра маркировки и функции маркировки элементарного сигнального графа БЗ. Построена фактуальная БЗ на основе подмножества лингвистического корпуса ликвидации и предотвращения аварий в энергосистеме. Построен специализированный тезаурус профессиональных терминов и сленга области ликвидации и предотвращения аварий в энергосистеме.

Научная новизна. Впервые предложен унифицированный подход к представлению и управлению профессиональными знаниями диспетчерского противоаварийного управления на базе модели сигнального графа. Это дает возможность строить эффективные системы поддержки решений и внедрять их в среду действующей АСДУ.

Практическая значимость. В работе предложено формирование новых онтологий баз знаний области диспетчерского управления режимами энергосистем в виде матриц чувствительности на основе факторных режимных моделей. Разработаны интегральные коэффициенты эффективности тезаурусов, позволяющие практически оценить эффективность разных форм репрезентации профессиональных знаний. Предложена структурная схема интеграции СППР в комплекс АСДУ - оперативный информационно-управляющий комплекс (ОИУК) для мониторинга режима электроэнергетической системы (ЭЭС) на основе эмпирической базы знаний о режимных характеристиках энергосистемы. Обобщение результатов испытаний программного комплекса при тренировках диспетчерского персонала энергосистемы подтвердило практическую значимость применения СППР в практике диспетчерского управления ЭЭС в аварийных ситуациях: повысились профессиональнопсихологические характеристики оперативного персонала, сократились интенсивность отказов диспетчерских смен и условный ущерб от недоотпуска электроэнергии.

Ключевые слова: онтология, база знаний, сигнальный граф, формальный язык, энергосистема

Recommended for publication by A. I. Kupin, Doctor of Technical Sciences. The manuscript was submitted 26.01.19. 